\title{
Using questionnaire surveys and occupancy modelling to identify conservation priorities for the Critically Endangered Balkan lynx Lynx lynx balcanicus
}

\author{
Dime Melovski, Manuela von Arx, Vasko Avukatov \\ Christine Breitenmoser-Würsten, Marina Đurović, Rafet Elezi \\ Olivier Gimenez, Bledi Hoxha, Slavcho Hristoviki, Guorgje Ivanov \\ Alexandros A. Karamanlidis, Tabea Lanz, Kujtim Mersini \\ Aleksandar Perović, Azem Ramadani, Bardh Sanaja, Parsim Sanaja \\ Gabriel Schinaderer, Annette Spangenberg, Aleksandar Stojanov \\ ALEKSANDËR TRAJÇE and URS BREITENMOSER
}

\begin{abstract}
With an estimated $<50$ adult individuals remaining, the Critically Endangered Balkan lynx Lynx lynx balcanicus is one of the rarest, most threatened and least-studied large carnivores. To identify priority conservation areas and actions for the subspecies, during 2006-2014 we conducted 1,374 questionnaire surveys throughout the potential range of the Balkan lynx to (1) evaluate human-lynx interactions and identify potential threats, and (2) determine the probability of site use in 207 grid cells through occupancy modelling. Human-lynx interactions were related mainly to
\end{abstract}

Dime Melovski ${ }^{*}$ (Corresponding author), Vasko Avukatov, Slavcho Hristovski†, GJorgje Ivanov and Aleksandar Stojanov Macedonian Ecological Society, Skopje, Macedonia. E-mail melovskid@mes.org.mk

Manuela von Arx, Christine Breitenmoser-Würsten, Tabea Lanz and Urs BreitenMoser $\ddagger$ KORA, Carnivore Ecology and Wildlife Management, Bern, Switzerland

Marina Đurović Public Enterprise for National Parks of Montenegro, Podgorica, Montenegro

Rafet Elezi and Azem Ramadani Finch, Prizren, Kosovo

OLIVIER Gimenez Centre d'Écologie Fonctionnelle et Évolutive, CNRS, Université Montpellier, Montpellier, France

Bledi Hoxha, Kujtim Mersini and Aleksandër Trajçe Protection and Preservation of Natural Environment in Albania, Tirana, Albania

Alexandros A. Karamanlidis Faculty of Environmental Sciences and Natural Resource Management, Norwegian University of Life Sciences, Ås, Norway

Aleksandar Perović Centre for Protection and Research of Birds, Podgorica, Montenegro

Bardh Sanaja and Parsim Sanaja Environmentally Responsible Action Group Peja, Kosovo

Gabriel Schwaderer and Annette Spangenberg EuroNatur Foundation, Radolfzell, Germany

*Also at: Faculty of Forest Sciences, Wildlife Sciences, University of Göttingen, Göttingen, Germany

$\dagger$ Also at: Institute of Biology, Faculty of Natural Sciences and Mathematics, Ss. Cyrill and Methodius University, Skopje, Macedonia

$\ddagger$ Also at: Centre for Fish and Wildlife Health, University of Bern, Bern, Switzerland

Received 21 December 2017. Revision requested 6 March 2018.

Accepted 26 March 2018. First published online 3 December 2018. poaching of lynx, and damage to livestock by lynx. Poaching was intense throughout the potential range of the subspecies, apparently having affected $50-100 \%$ of the total estimated extant population. Damage to livestock was recorded only in relation to sheep, mainly in the southern part of the lynx's potential range. Occupancy modelling indicated 108 grid cells with high probability of site use, which was affected mainly by increased terrain ruggedness and reduced forest cover. Based on the combined results of our study we identified five priority areas for conservation, as well as in situ habitat protection, community participation in the conservation of the subspecies, and the improvement and implementation of the existing legal framework as the priority conservation actions for the Balkan lynx.

Keywords Balkan lynx, conservation, Critically Endangered subspecies, distribution range, local ecological knowledge, occupancy modelling, questionnaire surveys

The data and $R$ code for the analyses are available at https://github.com/oliviergimenez/occ_balkanlynx

\section{Introduction}

T $\mathrm{n}$ the midst of a global biodiversity crisis (Butchart et al., 2010) Europe has been witnessing a resurgence in its wildlife, with several species showing signs of population recovery (Deinet et al., 2013). Because of the charismatic nature of large carnivores, and the challenges associated with effectively managing and protecting them, their recovery has received considerable public attention in Europe (Chapron et al., 2014). Large carnivores have been recovering across the continent, including the Balkan Peninsula (Karamanlidis et al., 2015; Ivanov et al., 2016); however, an exception to this positive development is the Critically Endangered Balkan lynx Lynx lynx balcanicus (Melovski et al., 2015). 
The Balkan lynx was described in the 2oth century (Bureš, 1941) but it was not until the early 21st century that genetic evidence indicated its taxonomic status as a subspecies of the Eurasian lynx Lynx lynx (BreitenmoserWürsten \& Obexer-Ruff, 2003; Gugolz et al., 2008). Although the phylogenetic relationship of the Balkan lynx to other subspecies of Eurasian lynx is still unclear, its morphological distinctiveness and isolation from the nearest lynx subspecies in the Carpathian Mountains (Mirić, 1978) justifies its recognition as a distinct evolutionary significant unit for conservation (Vogler \& Desalle, 1994).

Historically, the Balkan lynx suffered a fate similar to that of most other large carnivores in Europe, where increased habitat alteration and persecution led to its extermination from large parts of the continent (Breitenmoser, 1998). Following World War II legal and administrative actions resulted in the partial recovery of the subspecies; in 1974 the population was estimated to comprise 280 individuals, located mainly in the south-west of the Balkan Peninsula (Mirić, 1981). However, political unrest in the region at the turn of the century combined with habitat deterioration and poaching are believed to have led to a sharp population decline and range constriction, which has brought the Balkan lynx to the brink of extinction (Melovski, 2012): it is estimated that there are $<50$ adult individuals remaining in the wild, hence the subspecies' categorization as Critically Endangered on the IUCN Red List (Melovski et al., 2015). The Balkan lynx is legally protected in Albania, Kosovo (referred to according to U.N. Security Council Resolution 1244) and Macedonia (for reasons of neutrality and brevity the name Macedonia is used for the country with the constitutional name Republic of Macedonia, admitted to the UN under the provisional designation 'the former Yugoslav Republic of Macedonia'), and a compensation system for damage to livestock by lynx has been established in Macedonia. Effective conservation of biodiversity requires detailed, quantitative scientific information, which for many wildlife populations is not available (Gilchrist et al., 2005). There has therefore been increasing consensus among conservationists that alternative sources of information are necessary for protecting nature and that local ecological knowledge can provide important information on the status of wildlife populations and should be integrated in environmental management (Drew, 2005; Anadón et al., 2009).

Local ecological knowledge has been used to provide information on species' distributions and status over large landscapes, with moderate effort (Taubmann et al., 2016). However, there are limitations and caveats regarding its use (Caruso et al., 2017), especially when dealing with populations of large carnivores for which detectability is almost certainly $<_{1}$ (Louvrier et al., 2018), which can lead to false negatives (Kéry, 2011). Falsely assuming perfect detection can lead to an underestimation of the species' distribution
(Lahoz-Monfort et al., 2014). Therefore, site-occupancy models have been developed specifically to distinguish between non-detection and absence by modelling the imperfect, possibly heterogeneous observation process (MacKenzie, 2006). This modelling framework has been used successfully to analyse data from multiple interviewees reporting the detection or non-detection of large carnivores and to infer their distribution, accounting for imperfect detection (e.g. Petracca et al., 2014; Taubmann et al., 2016).

The main aims of this study were to use a questionnaire survey to (1) evaluate human-lynx interactions to identify potential threats to the survival of the Balkan lynx, and (2) determine the probability of site use. The results are used to identify research and conservation priorities to safeguard the survival of this subspecies.

\section{Study area}

The study was conducted in presumed distribution areas of the Balkan lynx (von Arx et al., 2004; Kaczensky et al., 2013a,b), including areas that were considered by Grubac $(2000,2002)$ to be potentially within the subspecies' range. We also included some localities outside the presumed area of distribution, for which circumstantial evidence indicated the presence of the subspecies (Grubač, 2002). Thus, the study area comprised $20,700 \mathrm{~km}^{2}$ of predominantly mountainous terrain in Albania, Kosovo, Macedonia and Montenegro (Fig. 1). The mean altitude of the villages where questionnaire surveys were carried out was $1,050 \mathrm{~m}$ and the mean human population density was 87.5 people per $\mathrm{km}^{2}$ (Kosovo Agency of Statistics, 2016; Institute of Statistics, Albania, 2016; Statistical Office of Montenegro, 2016; State Statistical Office, Macedonia, 2016). The vegetation in the study area is predominantly forest, with beech Fagus sylvatica, fir Abies borisii-regis and various types of oak Quercus spp. The region is characterized by high-mountain pastures, river valleys and rural anthropogenic landscapes.

\section{Methods}

\section{Sampling approach and data collection}

Following the design of similar surveys of large carnivores in Europe (e.g. Kaczensky et al., 2013a,b; Chapron et al., 2014) and taking into account the home ranges of the European (Breitenmoser-Würsten et al., 2007) and Balkan lynx (D. Melovski, unpubl. data), the study area was overlaid with the $10 \times 10 \mathrm{~km}$ Universal Transverse Mercator reference grid (UTM34N/WGS84) and 207 grid cells were selected that included the entire potential range of the Balkan lynx (Fig. 1). 


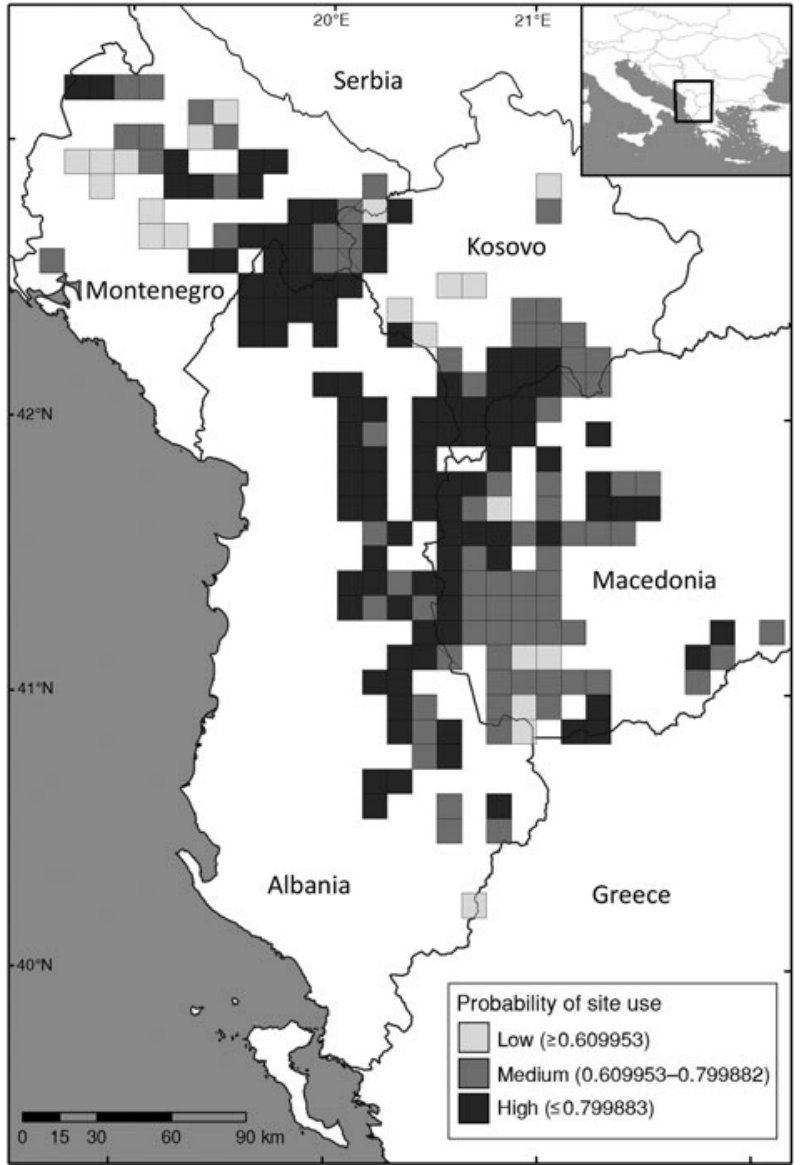

FIG. 1 The survey area in the south-western Balkans, showing the $20710 \times 10 \mathrm{~km}$ grid cells in which we conducted questionnaire surveys, with the probability of site use of the Balkan lynx Lynx lynx balcanicus as estimated through occupancy modelling.

During 2006-2014 we conducted systematic, face-toface questionnaire surveys, using local ecological knowledge to collect information on site use by large carnivores, and their interactions with people. In each of the grid cells we visited at least one village and interviewed up to eight people of various professional backgrounds (e.g. hunters, foresters, livestock breeders, beekeepers, farmers). We asked 55 quantitative and qualitative questions regarding the presence of large carnivores in the area, human-carnivore interactions, husbandry practices, and conservation issues; of the 55 questions, we used six related to human-lynx interactions, seven to lynx presence and one to site use, in the data analysis. We interviewed 1,374 people in total (Albania, 320; Kosovo, 235; Macedonia, 577; Montenegro, 242; mean 6.6 per grid cell). Hunters (34.3\%) comprised the largest group of interviewees, followed by livestock breeders $(9.7 \%)$, farmers $(9.6 \%)$, foresters $(4.7 \%)$ and shop owners (4.2\%). Local residents comprised $80.8 \%$ of interviewees, the remainder being seasonal residents in the study area.

\section{Data analysis}

Human-lynx interactions were evaluated using descriptive statistics. To estimate site use of the Balkan lynx we implemented a single-season occupancy model (MacKenzie et al., 2002). Such models use replicates in time and space to distinguish absence from imperfect detection. Grid cells were used as spatial replicates, and each interviewee was considered to be a replicate for one or several cells (Taubmann et al., 2016). We added three buffers related to the profiles of the survey participants (see Louvrier et al., 2018, for a similar approach), depending on their area of knowledge (Zeller et al., 2011). We considered hunters and sheep herders who owned $>30$ sheep to have an area of knowledge of $5 \mathrm{~km}$ radius around their place of residence; sheep herders who owned $<30$ sheep were considered to have an area of knowledge of $3 \mathrm{~km}$ radius; and people who did not belong to the aforementioned categories were considered to have an area of knowledge of $1 \mathrm{~km}$ radius. We estimated the probability of site use, accounting for imperfect detection. Although the home ranges of female Balkan lynx match the size of our sampling unit, males tend to have larger home ranges. As a consequence, and assuming that movements are random, we interpreted occupancy as site use rather than the proportion of the area occupied by the subspecies (MacKenzie \& Nichols, 2004), usually referred to as third-order selection (Johnson, 1980). As people's various levels of experience in the field can lead to differences in their ability to detect a species (Davis \& Wagner, 2003), we considered a covariate for the level of expertise (i.e. a continuous variable with values of $1-5$, from the most to the least experienced observer) on the detection probability, to address this issue. The level of expertise was evaluated subjectively while conducting the interviews. To account for heterogeneity in the sampling effort we also considered the number of interviewees per cell as a covariate potentially affecting the detection probability. With regard to the probability of site use we used the proportion of forest cover (i.e. forest cover was estimated using a selection of natural and semi-natural land-cover categories of the Corine Land Cover 2012 vector data); terrain ruggedness generated from a Shuttle Radar Topography Mission (SRTM) digital elevation model using the 'ruggedness index' tool in QGIS v.2.16.2 (Quantum GIS Development Team, 2016); and altitude (SRTM digital elevation model; USGS, 2015) as sitespecific covariates potentially affecting site use and detection (Long et al., 2007; Karanth et al., 2009; MartínezMartí et al., 2016). Site covariates were averaged for the entire sampling unit, standardized by centring on their mean value, scaled by the standard deviation and incorporated in the model through logistic-linear relationships, except for altitude, for which we also considered a potential optimum through a logistic-quadratic relationship. We considered 192 models, which were fitted using the package 
TABLE 1 Model selection results, ranked by Akaike information criterion corrected for small sample size (AICc), for occupancy modelling to identify conservation priorities for the Balkan lynx Lynx lynx balcanicus. Of the 192 models fitted, only those with $\Delta$ AICc $<2$ are reported.

\begin{tabular}{|c|c|c|}
\hline Model $^{1}$ & $\mathrm{AICc}$ & $\Delta \mathrm{AICc}^{2}$ \\
\hline $\mathrm{p}($ forest + expert + rug + sampeff $) \psi($ forest + rug $)$ & 4157.8 & 0 \\
\hline $\mathrm{p}($ forest + expert + rug + sampeff $) \psi($ forest + rug + alt $)$ & 4158.5 & 0.70 \\
\hline $\mathrm{p}($ forest + expert + rug + sampeff $) \psi\left(\right.$ forest + rug + alt $\left.+\mathrm{alt}^{2}\right)$ & 4159.4 & 1.62 \\
\hline
\end{tabular}

${ }^{1} \mathrm{p}$, detection probability; $\psi$, occupancy probability. Covariates: forest, proportion of forest cover; expert, level of expertise; rug, terrain ruggedness; sampeff, number of respondents; alt, altitude.

${ }^{2} \triangle \mathrm{AICc}$, difference between the AICc of the current model and the AICc of the model with the lowest AICc.

unmarked in $R$ v.3.5.o (Fiske \& Chandler, 2011) and compared using the Akaike information criterion corrected for small sample size (AICc; Burnham \& Anderson, 2002). To account for model selection uncertainty we used model averaging as implemented in the $R$ package MuMIn (Barton, 2016), considering all models with $\triangle \mathrm{AIC}<2$, where $\Delta$ AIC is the difference between the AICc of a given model and the AICc of the model with the lowest AICc. We built an occupancy map by calculating the estimated probability of site use for a given grid cell using the model-averaged parameter estimates and the value of the covariates for this cell. The resulting map depicts lynx presence as reflected in the questionnaires, and we assume that interviewees' perception of lynx presence indicates actual lynx presence. Probability of site use values were used to group the cells into three categories using the Jenks optimization method (Jenks, 1967): low (probability of site use $\leq 0.609953$ ), medium (0.609953 $<$ probability of site use $\leq 0.799882$ ) and high (probability of site use $\geq 0.799883$ ) (Fig. 1).

\section{Results}

\section{Human-lynx interactions}

The questionnaires recorded quantitative and qualitative data on various types of human-lynx interactions; however, the data facilitated evaluation of only the following three types of interactions: poaching of lynx, damage to livestock by lynx, and lynx-vehicle collisions.

Lynx poaching was reported by 66 interviewees (Albania, 28; Kosovo, 7; Macedonia, 23; Montenegro, 8) in 38 locations in the study area. Eleven interviewees reported killing lynx, and 55 reported indirect knowledge of lynx being killed. Most poaching cases (48) were reported to have taken place in the border areas of Macedonia and Albania, and Albania and Montenegro (Fig. 2a) after 2000. On 24 occasions (Albania, 7; Kosovo, 1; Macedonia, 12; Montenegro, 4) the survey teams were able to verify lynx poaching either by inspecting pelts, trophies and stuffed animals or by evaluating photographs.

On 19 occasions interviewees reported that lynx had attacked their livestock. The attacks occurred in 15 villages, mainly in western and southern Macedonia (Fig. 2b), within 12 months prior to the interview. Attacks were recorded for sheep that were protected by guarding dogs (in 14 cases), shepherds (16) or a combination of shepherds and dogs (13), and sheep that were penned at night (12). Only two cases were reported to the relevant authorities and no compensation was received. To mitigate damage to livestock by lynx, shepherds used various measures, including moving herds to other grazing areas (4 cases), intensifying herding ( 7 ), and hunting or poisoning lynx (13). Two collisions of lynx with vehicles on secondary roads in western Macedonia were also recorded.

\section{Site use}

The top-ranked single-season occupancy models $(\triangle \mathrm{AICc}<2$, cumulative AIC weight 0.98$)$ included an effect of the number of interviewees (model-averaged estimate $=0.19 \pm \mathrm{SE} 0.03)$, terrain ruggedness $(0.48 \pm \mathrm{SE} 0.06$ ), forest cover $(-0.40 \pm S E 0.05)$ and level of expertise (0.21 \pm SE 0.04$)$ on the detection probability, and an effect of forest cover $(-0.85 \pm \mathrm{SE} 0.30)$ and terrain ruggedness $(1.20 \pm$ SE 0.38$)$ on the site use probability (Table 1). There was some uncertainty regarding the altitude covariate and whether or not it had an effect on the probability of site use (model-averaged estimate linear term $=-0.18 \pm$ SE 0.27 , quadratic term $=-0.04 \pm$ SE 0.10 ).

The site-use map resulting from the model-averaged parameter estimates included 21 areas with low probability of site use, mainly in south-western Montenegro and central Kosovo, 78 areas with medium probability of site use, mainly in south-western parts of Macedonia and southern Kosovo, and 108 areas with high probabilities of site use, mainly in the border region of Albania-Kosovo and Albania-Macedonia, central and central-south Albania, and in the border region of Albania and Montenegro (Fig. 1).

\section{Discussion}

The Balkan lynx is the least studied and known large carnivore in Europe. With an estimated total population of $<50$ adult individuals in the wild, identifying human-lynx interactions and estimating site use should be considered 
important research priorities for the subspecies (Inskip \& Zimmermann, 2009). Our study provides the first widescale assessment of the subspecies' interactions with people, and its potential occupancy throughout its range.

Poaching is a common and globally recognized challenge to the conservation of wildlife, especially for large carnivores (Ripple et al., 2014). Although it is difficult, given its illegal nature, to evaluate accurately its effect on population dynamics (Liberg et al., 2012), poaching appears to have been an important factor in the mortality of lynx in Europe, and a threat to the species' conservation (Červený et al., 2002). This appears also to be the case for the Balkan lynx, with the survey results indicating that since the beginning of this century the equivalent of $50-100 \%$ of the total estimated, currently surviving population could have fallen victim to poaching. However, this statement should be considered cautiously, as during our questionnaire we were unable to determine if the 66 reported cases of lynx poaching referred to unique cases or if there was a degree of overlap.

Damage to livestock by large carnivores is one of the most common causes of conflict between people and carnivores worldwide (Kaczensky, 1999) and poses an important conservation challenge in the recovery of several lynx populations in Europe (Trouwborst, 2010). However, the number of incidents of depredation recorded in our study was small, probably as a result of the relatively good herding practices in the area (i.e. use of guarding dogs and shepherds, and penning at night); however, this could also be regarded as a measure to protect against other, more damaging large carnivores, such as wolves Canis lupus and bears Ursus arctos. The fact that the majority of sheep herders did not seek compensation for damage because of distrust in the compensation system or because they did not know that such a system existed indicates that the design of the damage compensation system needs improvement. Improvements to the damage compensation system in Macedonia should include more rigorous damage evaluation procedures, resulting in the swifter delivery of compensation (Karamanlidis et al., 2011), and information campaigns to make the compensation system more accessible. Modern compensation schemes can be designed in such a way that they alleviate the financial losses from livestock depredation but also aim to reduce poaching of large carnivores (Treves et al., 2006).

Road mortality can affect wildlife through habitat fragmentation and reduced gene flow (Clevenger et al., 2001). During the study only two road mortalities were recorded throughout the entire potential range of the subspecies, and therefore road mortality should not currently be regarded as a major threat to its survival. However, considering the conservation status of the Balkan lynx and the economic development currently taking place throughout its range, care should be taken in the spatial planning and construction of the road network (Kusak et al., 2009) to avoid the development of a new conservation threat.
As identified in the IUCN Red List assessment (Melovski et al., 2015), habitat degradation and prey depletion are significant factors contributing to the decline of the Balkan lynx. Forest degradation, which has been reported as one of the main conservation threats for lynx throughout Europe (Breitenmoser et al., 200o), appeared to be intensive throughout the entire potential range of the Balkan lynx, including the areas of high probability of site use; this is in accordance with information from the area (Albania, Stahl, 2010; Macedonia, Kolevska et al., 2017). Prey depletion is a conservation threat for lynx in Eastern Europe (Schmidt, 2008a,b; Yom-Tov et al., 2011) and could also play a negative role in the survival of the Balkan lynx. As no causative effect for prey depletion could be established in this study, dedicated research is necessary to evaluate the impact of this threat on the survival of the subspecies; this should be one of the research priorities for the Balkan lynx.

Interview-based surveys provide a cost-effective and logistically practical alternative to time-consuming and capacity-demanding field surveys, especially for large carnivores that are rare and difficult to detect (Gros et al., 1996). However, evaluation of local ecological knowledge is not an objective way to assess people's generic reports (Huntington, 200o). We discovered that rare and/or spectacular events, such as the sighting of a lynx, are remembered for a long time, and this could have influenced the site occupancy analysis. The shortcoming of the low detectability of the lynx, a result of their cryptic nature and low abundance, was accounted for through the occupancy framework, which addresses imperfect detection (Taubmann et al., 2016).

Using this methodology we provide the first map of the probability of site use of the Balkan lynx in the southwestern Balkans. Lynx detectability was positively affected by the number of interviewees, their level of expertise, and terrain ruggedness, and negatively affected by the percentage of forest cover. These results are consistent with our expectations. However, our occupancy modelling results are more difficult to interpret, as they were positively affected by terrain ruggedness, but negatively affected by forest cover. Lynx presence is generally associated with rugged, forested areas (Lone et al., 2014). However, research has shown that in human-modified areas (such as those throughout our study area) lynx may exhibit nuanced behavioural responses and select areas with medium levels of human modification, avoiding areas with high or low levels of modification (Bouyer et al., 2015). Considering that our results depict only the human perception of lynx habitat use, and given the lack of relevant telemetry data, we believe that studying Balkan lynx habitat use should be a research priority.

Information provided by local people in interview-based surveys may include errors (e.g. false positive detections) that can produce biased results in occupancy studies (Miller et al., 2013). To mitigate such errors we recommend 

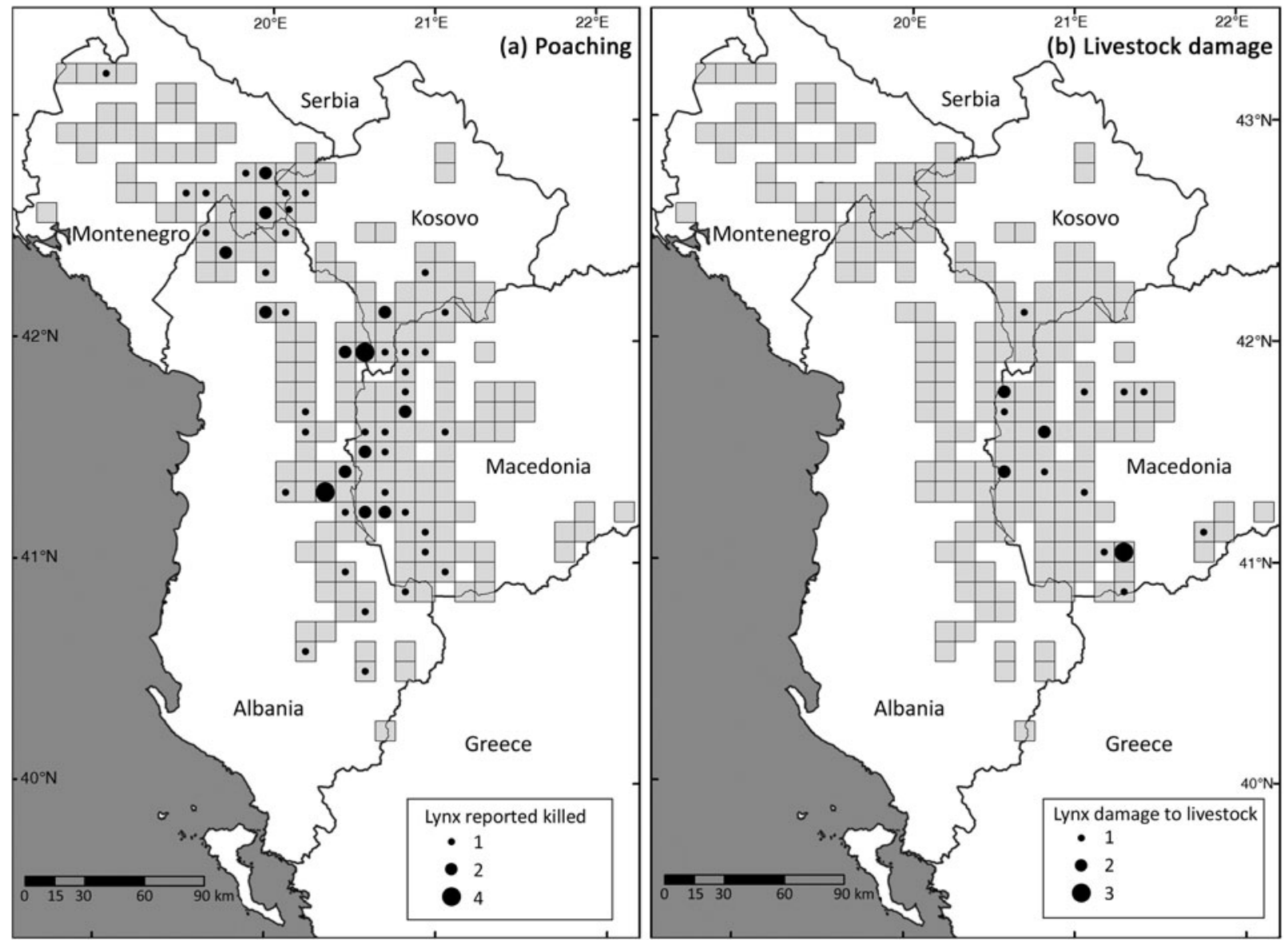

FIG. 2 Survey grid cells in which interviewees indicated Balkan lynx (a) had been poached, and (b) had caused damage to their livestock.

the use of site-occupancy models accounting for false positives, which have been applied to data collected via interview-based surveys (Pillay et al., 2014). If a similar survey were to be conducted in 10 years time, we recommend using the same questionnaire, to assess trends in the dynamics of occupancy by considering local extinction and colonization events with dynamic occupancy models (e.g. Taubmann et al., 2016).

Our results on lynx-human interactions (Fig. 2) and on the probability of site use (Fig. 1) together indicate that the Balkan lynx is most likely to occur in the border region between the four countries in the study area, as well as in some parts of central, northern and southern Albania. Evaluating the results of our study in conjunction with information from dedicated, localized studies on lynx presence and behaviour using various methodologies (Melovski et al., 2009, 2011; PPNEA, 2014; Stojanov et al., 2015) we identify five priority conservation areas for the Balkan lynx (Fig. 3). Two of these areas emerge as the core areas of the surviving Balkan lynx population: Mavrovo National Park in Macedonia (Fig. 3, area 2) and the Munella Mountains in central-north Albania (Fig. 3, area 4) (Melovski et al., 2013). The other three areas that should be considered important for the recovery of the Balkan lynx (Fig. 3) and protected effectively (Schwaderer et al., 2008) are the Macedonian part of the Shar Planina Mountains (Fig. 3, area 3), the ShebenikJablanica Mountains (Fig. 3, area 1) and the Albanian Alps (Fig. 3, area 5).

\section{Conservation priorities}

With well-planned conservation action, carnivore populations should continue to survive despite human population growth and modification of habitat. Based on the results and experiences of our interview-based survey, and taking into account conservation threats, priorities and solutions from other, better-studied lynx populations in Europe (Breitenmoser et al., 2000), we identify three main conservation priorities for the Balkan lynx that should be implemented on both a local and wider geographical scale:

(1) Conservation efforts should focus on protecting the remaining populations in situ, their critical habitat and their prey base (Breitenmoser et al., 2008). Actions should focus primarily on the priority conservation areas identified and should include law enforcement 


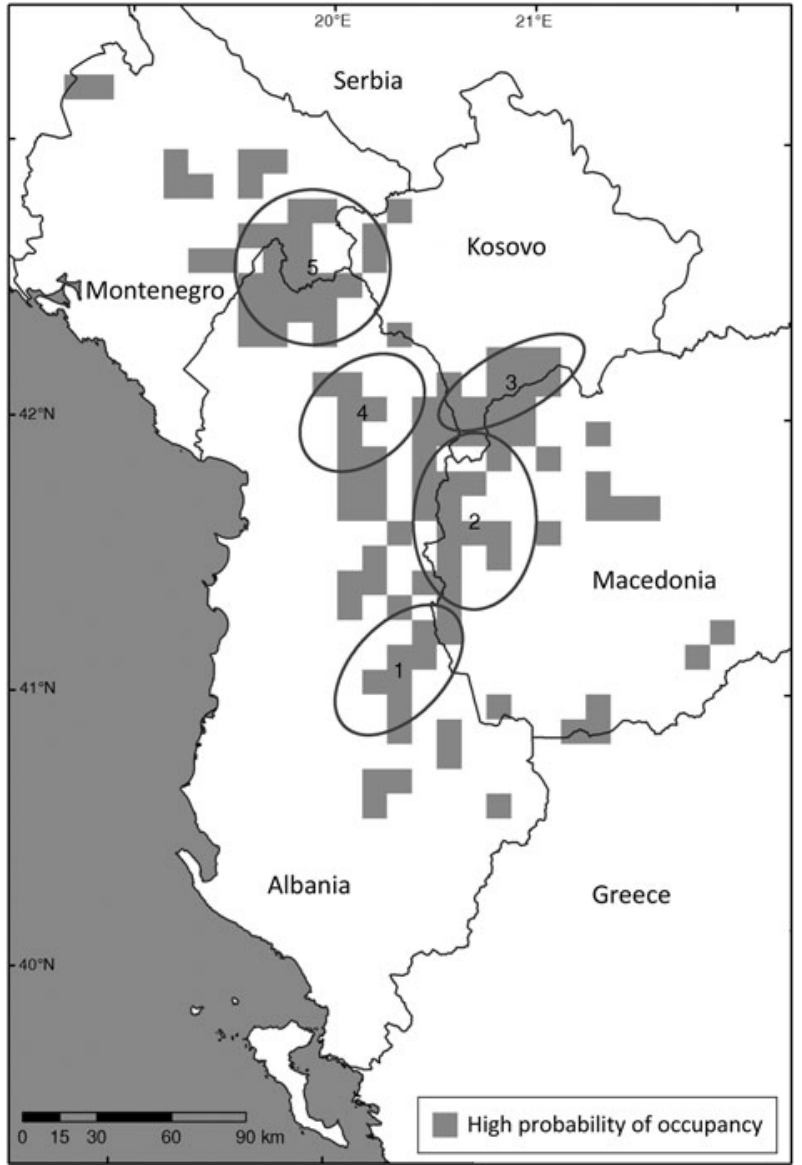

FIG. 3 Five important areas for the conservation of the Balkan lynx, identified based on occupancy modelling (Fig. 1) and questionnaire surveys (Fig. 2): 1, Shebenik-Jablanica and surroundings; 2, Mavrovo National Park and surroundings; 3, Shar Planina Mountain; 4, Munella Mountains and surroundings; 5, Albanian Alps.

and management actions (i.e. scientific monitoring of local lynx populations, forest management, restoration of habitats and improvement of compensation systems) in the areas that already have a legally protected status (Mavrovo National Park), and the designation of new protected areas for the subspecies (Munella Mountains in central-north Albania).

(2) Active participation and involvement of various stakeholder groups in the conservation of this subspecies is important. In the case of the Balkan lynx it is crucial to involve hunters in the conservation process, as they can play an important role in reducing poaching and prey depletion, and in participating in monitoring.

(3) Despite the Balkan lynx being protected throughout its range, trophies can still be found in cafeterias in rural settlements throughout its range, yet cases of poaching of the subspecies have never been prosecuted. It is necessary to improve and enforce the legal framework for the protection of the Balkan lynx effectively, to prevent the extinction of this rare subspecies.
Acknowledgements The questionnaire surveys were carried out within the framework of the Balkan Lynx Recovery Programme funded by the MAVA foundation, Switzerland. All research activities were carried out under the research permits 11-10190/2/20.11.2009, 11-2186/ 2/19.02.2010 and 11-546/2/29.01.2013 issued by the Macedonian Ministry of Environment and Physical Planning; and protocol number 2777/22.12.2009 of the Albanian Ministry of Environment, Forests and Water Administration, Directorate of Nature Protection Policies.

Author contributions Research conceptualization and design: DM, MvA, AAK, SH, GS, ASP, UB; data collection: DM, MĐ, RE, BH, GjI, KM, AP, AR, BS, PS, AST, AT; statistical analysis: DM, VA, OG, AAK; preparation of maps and creation of the common database: VA; writing: all authors.

\section{Conflicts of interest None.}

Ethical standards All interviews in this study were conducted with prior consent of the interviewees, who had the option of remaining anonymous.

\section{References}

Anadón, D.J., Giménez, A., Ballestar, R. \& Pérez, I. (2009) Evaluation of local ecological knowledge as a method for collecting extensive data on animal abundance. Conservation Biology, 23, 617-625.

B ARTOŃ, K. (2016) MuMIn: Multi-Model Inference. $R$ package version 1.15.6.

Bouyer, Y., San Martin, G., Poncin, P., Beudels-Jamar, R.C., Odden, J. \& Linnell, J.D.C. (2015) Eurasian lynx habitat selection in human-modified landscape in Norway: effects of different human habitat modifications and behavioral states. Biological Conservation, 191, 291-299.

Breitenmoser, U. (1998) Large predators in the Alps: the fall and rise of man's competitors. Biological Conservation, 83, 279-289.

Breitenmoser, U., Breitenmoser-Wúrsten, C., Okarma, H., Kaphegyi, T., Kaphegyi-Wallmann, U. \& Müller, U.M. (2000) Action Plan for the Conservation of the Eurasian Lynx in Europe. Council of Europe, Strasbourg, France.

Breitenmoser, U., von Arx, M., Bego, F., Ivanov, G., Keçi, E., MelovsKi, D. et al. (2008) Strategic planning for the conservation of the Balkan lynx. In Proceedings of the III Congress of Ecologists of the Republic of Macedonia with International Participation, pp. 242-248. Macedonian Ecological Society, Struga, FYR Macedonia.

Breitenmoser-Wúrsten, C. \& Obexer-Ruff, G. (2003) Population and conservation genetics of two re-introduced lynx (Lynx lynx) populations in Switzerland - a molecular evaluation 30 years after translocation. In Proceedings of the 2nd Conference on the Status and Conservation of the Alpine Lynx Population (SCALP), pp. 28-31. Amden, Switzerland.

Breitenmoser-Würsten, C., Zimmermann, F., Stahl, P., Vandel, J.-M., Molinari-Jobin, A., Molinari, P. et al. (2007) Spatial and social stability of a Eurasian lynx Lynx lynx population: an assessment of 10 years of observations in the Jura Mountains. Wildlife Biology, 13, 365-380.

Bureš, I. (1941) Risove v Makedonija (Lynx in Macedonia). Priroda, 42, 51-52.

Burnham, K.P. \& Anderson, D.R. (2002) Model Selection and Inference: A Practical Information Theoretic Approach. Springer, New York, USA.

Butchart, S.H.M., Walpole, M., Collen, B., van Strien, A., Scharlemann, J.P.W., Almond, R.E.A. et al. (2010) Global biodiversity: indicators of recent declines. Science, 328, 1164-1168. 
Caruso, N., Vidal, E.L., Guerisoli, M. \& Lucherini, M. (2017) Carnivore occurrence: do interview-based surveys produce unreliable results? Oryx, 51, 240-245.

Červený, J., Koubek, P. \& Bufka, L. (2002) Eurasian lynx (Lynx lynx) and its chance for survival in Central Europe: the case of the Czech Republic. Acta Zoologica Lituanica, 12, 428-432.

Chapron, G., Kaczensky, P., Linnell, J.D.C., von Arx, M., Huber, D., ANDRÉn, H. et al. (2014) Recovery of large carnivores in Europe's modern human-dominated landscapes. Science, 346, 1517-1519.

Clevenger, A.P., Chruszcz, B. \& Gunson, K.E. (2001) Highway mitigation fencing reduces wildlife-vehicle collisions. Wildlife Society Bulletin, 29, 646-653.

Davis, A. \& WAGNeR, J.R. (2003) Who knows? On the importance of identifying "experts" when researching local ecological knowledge. Human Ecology, 31, 463-489.

Deinet, S., Ieronymidou, C., McRae, L., Burfield, I.J., Foppen, R. P., Collen, B. \& Böнm, M. (2013) Wildlife Comeback in Europe: The Recovery of Selected Mammal and Bird Species. ZSL, London, UK.

DrEW, J.A. (2005) Use of traditional ecological knowledge in marine conservation. Conservation Biology, 19, 1286-1293.

FisKe, I. \& CHANDLER, R.B. (2011) unmarked: An $R$ package for fitting hierarchical models of wildlife occurrence and abundance. Journal of Statistical Software, 43, 1-23.

Gilchrist, G., Mallory, M. \& Merkel, F. (2005) Can local ecological knowledge contribute to wildlife management? Case studies of migratory birds. Ecology and Society, 10(1), 20.

Gros, P.M., Kelly, M.J. \& Caro, T.M. (1996) Estimating carnivore densities for conservation purposes: indirect methods compared to baseline demographic data. Oikos, 77, 197-206.

Grubač, B. (2000) The lynx (Lynx lynx) in Serbia. Zaštita prirode 52 , $151-173$.

Grubač, B. (2002) Contribution on the Balkan lynx Lynx lynx martinoi (Mirić, 1978) in Macedonia and Montenegro. Zaštita prirode, 53, 37-47.

Gugolz, D., Bernasconi, M.V., Breitenmoser-Würsten, C. \& WAmdeler, P. (2008) Historical DNA reveals the phylogenetic position of the extinct Alpine lynx. Journal of Zoology, 275, 201-208.

HUNTINGTON, H.P. (2000) Using traditional ecological knowledge in science: methods and applications. Ecological Applications, 10, 12701274.

Inskip, C. \& ZimmermanN, A. (2009) Human-felid conflict: a review of patterns and priorities worldwide. Oryx, 43, 18-34.

Institute of Statistics, Albania (2016) Http://www.instat.gov.al [accessed November 2018].

Ivanov, G., Karamanlidis, A.A., Stojanov, A., Melovski, D. \& Avukatov, V. (2016) The re-establishment of the golden jackal (Canis aureus) in FYR Macedonia: implications for conservation. Mammalian Biology, 81, 326-330.

JENKs, G.F. (1967) The data model concept in statistical mapping. International Yearbook of Cartography, 7, 186-190.

Johnson, D.H. (1980) The comparison of usage and availability measurements for evaluating resource preference. Ecology, 61, 65-71.

Kaczensky, P. (1999) Large carnivore depredation on livestock in Europe. Ursus, 11, 59-72.

Kaczensky, P., Chapron, G., von Arx, M., Huber, Đ., Andrén, H. \& Linnell, J. (2013a) Status, Management and Distribution of Large Carnivores - Bear, Lynx, Wolf \& Wolverine - in Europe. Part 1. Report prepared with the assistance of Istituto di Ecologia Applicata and with the contributions of the IUCN/SSC Large Carnivore Initiative for Europe under contract No70307/2012/ 629085/SER/B3.

Kaczensky, P., Chapron, G., von Arx, M., Huber, Đ., Andrén, H. \& Linnell, J. (2013b) Status, Management and Distribution of Large Carnivores - Bear, Lynx, Wolf \& Wolverine - in Europe. Part 2.
Report prepared with the assistance of Istituto di Ecologia Applicata and with the contributions of the IUCN/SSC Large Carnivore Initiative for Europe under contract No70307/2012/629085/SER/B3.

Karamanlidis, A.A., Sanopoulos, A., Georgiadis, L. \& Zedrosser, A. (2011) Structural and economic aspects of humanbear conflicts in Greece. Ursus, 22, 141-151.

Karamanlidis, A.A., de Gabriel Hernando, M., Krambokoukis, L. \& Gimenez, O. (2015) Evidence of a large carnivore population recovery: counting bears in Greece. Journal for Nature Conservation, $27,10-17$.

Karanth, K.K., Nichols, J.D., Hines, J.E., Karanth, K.U. \& Christensen, N.L. (2009) Patterns and determinants of mammal species occurrence in India. Journal of Applied Ecology, 46, 11891200.

KérY, M. (2011) Towards the modelling of true species distributions. Journal of Biogeography, 38, 617-618.

Kolevska, D.D., Blinkov, I., Trajkov, P. \& Maletić, V. (2017) Reforestation in Macedonia: history, current practice and future perspectives. Reforesta, 3, 155-184.

Kosovo Agency of Statistics (2016) Http://ask.rks-gov.net/en/ kosovo-agency-of-statistics [accessed November 2018].

Kusak, J., Huber, D., Gomerčić, T., Schwaderer, G. \& Gužvica, G. (2009) The permeability of highway in Gorski kotar (Croatia) for large mammals. European Journal of Wildlife Research, 55, 7-21.

Lahoz-Monfort, J.J., Guillera-Arroita, G. \& Wintle, B.A. (2014) Imperfect detection impacts the performance of species distribution models. Global Ecology and Biogeography, 23, 504-515.

Liberg, O., Chapron, G., Wabakken, P., Pedersen, H.C., Hobbs, N.T. \& SAND, H. (2012) Shoot, shovel and shut up: cryptic poaching slows restoration of a large carnivore in Europe. Proceedings of the Royal Society B, 279, 910-915.

Lone, K., Loe, L.E., Gobakken, T., Linnell, J.D.C., Odden, J., Remmen, J. \& Mysterud, A. (2014) Living and dying in a multipredator landscape of fear: roe deer are squeezed by contrasting pattern of predation risk imposed by lynx and humans. Oikos, 123, 641-651.

Long, R.A., Donovan, T.M., MacKay, P., Zielinski, W.J. \& Buzas, J.S. (2007) Effectiveness of scat detection dogs for detecting forest carnivores. Journal of Wildlife Management, 71, 2007-2017.

Louvrier, J., Duchamp, C., Lauret, V., Marboutin, E., Cubaynes, S., Choquet, R. et al. (2018) Mapping and explaining wolf recolonization in France using dynamic occupancy models and opportunistic data. Ecography, 41, 647-66o.

MacKenzie, D.I. (2006) Occupancy Estimation and Modeling: Inferring Patterns and Dynamics of species Occurrence. Academic Press, London, UK.

MacKenZie, D.I. \& Nichols, J.D. (2004) Occupancy as a surrogate for abundance estimation. Animal Biodiversity and Conservation, $27,461-467$.

MacKenzie, D.I., Nichols, J.D., Lachman, G.B., Droege, S., Andrew Royle, J. \& Langtimm, C.A. (2002) Estimating site occupancy rates when detection probabilities are less than one. Ecology, 83, 2248-2255.

Martínez-Martí, C., Jiménez-Franco, M.V., Royle, J.A., PaLAzón, J.A. \& CALvo, J.F. (2016) Integrating occurrence and detectability patterns based on interview data: a case study for threatened mammals in Equatorial Guinea. Scientific Reports, 6, 33838 .

Melovski, D. (2012) Status and distribution of the Balkan lynx (Lynx lynx martinoi Mirić 1978) and its prey. MSc thesis. University of Montenegro, Montenegro.

Melovski, D., Ivanov, G., Stojanov, A., Trajçe, A., Zimmermann, F. \& von Arx, M. (2009) First camera-trap survey in the National Park Mavrovo, Macedonia. In International 
Conference on Biological and Environmental Sciences, pp. 312-315. University of Tirana, Tirana, Albania.

Melovski, D., Stojanov, A. \& Ivanov, G. (2011) Status, Ecology and Land Tenure System of the Critically Endangered Balkan Lynx in Macedonia and Albania. Radio-telemetry annual report, capture session 2011. Unpublished report. MES, Skopje, Republic of Macedonia.

Melovski, D., Ivanov, G., Stojanov, A., Trajce, A., Hoxha, B., vON ARX, M. et al. (2013) Distribution and conservation status of the Balkan lynx (Lynx lynx balcanicus Bureš, 1941). In Proceedings of the IV Congress of Ecologists of the Republic of Macedonia with International Participation, pp. 50-6o. Macedonian Ecological Society, Ohrid, Macedonia.

Melovski, D., Breitenmoser, U., von Arx, M., Breitenmoser-Wúrsten, C. \& Lanz, T. (2015) Lynx lynx ssp. balcanicus. The IUCN Red List of Threatened Species. Http://dx.doi. org/10.2305/IUCN.UK.2015-4.RLTS.T68986842A68986849.en [accessed 4 August 2016].

Miller, D.A.W., Nichols, J.D., Gude, J.A., Rich, L.N., Podruzny, K.M., Hines, J.E. \& Mitchell, M.S. (2013) Determining occurrence dynamics when false positives occur: estimating the range dynamics of wolves from public survey data. PLoS ONE, 8(6), e65808.

MirIĆ, Đ. (1978) Lynx lynx martinoi ssp. nova (Carnivora, Mammalia) - neue Luchsunterart von der Balkanhalbinsel. Bulletin of the Museum of Natural History of Belgrade, B33, 29-36.

Mirić, Đ. (1981) The lynx populations of the Balkan Peninsula (Mirić, 1978). Pos. izd. SANU 139, Odel prir.-mat. nauka, 55, 1-154.

Petracca, L.S., Ramírez-Bravo, O.E. \& Hernández-Santín, L. (2014) Occupancy estimation of jaguar Panthera onca to assess the value of east-central Mexico as a jaguar corridor. Oryx, 48, 133-140.

Pillay, R., Miller, D.A.W., Hines, J.E., Joshi, A.A. \& Madhusudan, M.D. (2014) Accounting for false positives improves estimates of occupancy from key informant interviews. Diversity and Distributions, 20, 223-235.

PPNeA (Protection and Preservation of Natural Environment in Albania) (2014) Report on the Munella mountain, summary of the findings from the Balkan lynx recovery programme. Unpublished report. PPNEA, Tirana, Albania.

Quantum GIS Development Team (2016) Quantum GIS Geographical Information System. Open Source Geospatial Foundation Project, Beaverton, USA.

Ripple, W.J., Estes, J.A., Beschta, R.L., Wilmers, C.C., Ritchie, E. G., Hebblewhite, M. et al. (2014) Status and ecological effects of the world's largest carnivores. Science, 343, 1241484.

Schmidt, K. (2008a) Behavioural and spatial adaptation of the Eurasian lynx to a decline in prey availability. Acta Theriologica, 53, $1-16$.
Schmidt, K. (2008b) Factors shaping the Eurasian lynx (Lynx lynx) population in the north-eastern Poland. Nature Conservation, 65 , $3^{-15}$.

Schwaderer, G., Spangenberg, A., Melovisi, D., Trajçe, A. \& Bego, F. (2008) Protected area in species conservation - the protected area component within the frame of the Balkan Lynx Recovery Programme. In Proceedings of the III Congress of Ecologists of Macedonia with International Participation, pp. 265-269. Macedonian Ecological Society, Skopje.

Stahl, J. (2010) The rents of illegal logging: the mechanisms behind the rush on forest resources in southeast Albania. Conservation \& Society, 8, 140-150.

State Statistical Office, Macedonia (2016) Http://www.stat. gov.mk [accessed November 2018].

Statistical Office of Montenegro (2016) Http://www.monstat. org [accessed November 2018].

Stojanov, A., Melovski, D., Sarov, A., Ivanov, G. \& Avukatov, V. (2015) Deterministic camera-trapping study in Mavrovo National Park, Macedonia in 2015. Unpublished report. MES, Skopje, Republic of Macedonia.

Taubmann, J., Sharma, K., Uulu, K.Z., Hines, J.E. \& Mishra, C. (2016) Status assessment of the Endangered snow leopard Panthera uncia and other large mammals in the Kyrgyz Alay, using community knowledge corrected for imperfect detection. Oryx, 50, 220-230.

Treves, A., Wallace, R.B., Naughton-Treves, L. \& Morales, A. (2006) Co-managing human-wildlife conflicts: a review. Human Dimensions of Wildlife, 11, 383-396.

Trouwborst, A. (2010) Managing the carnivore comeback: international and EU species protection law and the return of lynx, wolf and bear to Western Europe. Journal of Environmental Law, 22, 347-372.

USGS (United S tates Geological Survey) (2015) Shuttle Radar Topography Mission, 1 Arc Second Multiple Digital Elevation Model Scenes Covering the Balkan Peninsula. Global Land Cover Facility, University of Maryland, College Park, Maryland.

Vogler, P.A. \& Desalle, R. (1994) Diagnosing units of conservation management. Conservation Biology, 8, 354-363.

von Arx, M., Breitenmoser-Würsten, C., Zimmermann, F. \& Breitenmoser, U. (2004) Status and Conservation of the Eurasian Lynx (Lynx lynx) in Europe in 2001. KORA, Bern, Switzerland.

Yom-Tov, Y., Kvam, T. \& WIIG, Ø. (2011) Lynx body size in Norway is related to its main prey (roe deer) density, climate, and latitude. Ambio, 40, 43-51.

Zeller, K.A., Nijhawan, S., Salom-Pérez, R., Potosme, S.H. \& Hines, J.E. (2011) Integrating occupancy modeling and interview data for corridor identification: a case study for jaguars in Nicaragua. Biological Conservation, 144, 892-901. 